\title{
Power Quality Improvement in Distribution Systems Considering Optimum D-STATCOM Placement
}

\author{
(Peningkatan Kualiti Kuasa dalam Sistem Pengagihan Berdasarkan Penempatan D-STATCOM Optimum)
}

Masoud Farhoodnea*, Azah Mohamed, Hussain Shareef \& Hadi Zayandehroodi

\begin{abstract}
This paper presents an improved method in solving the optimization problem related to the optimum placement and sizing of the Distribution Static Synchronous Compensator (D-STATCOM) in distribution systems, which use the firefly algorithm (FA) for power quality improvement. In the proposed method, the voltage total harmonic distortion, voltage deviation, and total investment cost indices are considered as the problem sub-objective functions. The voltage and power limits for individual buses are considered as the constraints to control optimization variables. The proposed FA is implemented using the Matlab software on modified IEEE 16- and 34-bus test systems. The obtained results are compared with the particle swarm optimization and the genetic algorithm. The simulation and comparison results verify the ability of the FA to accurately determine the optimal location and size of the D-STATCOM in radial distribution systems.
\end{abstract}

Keywords: D-STATCOM; optimal placement; firefly algorithm; voltage sag

ABSTRAK

Kertas kerja ini membentangkan kaedah yang ditambahbaik bagi menyelesaikan masalah pengoptimuman berkaitan dengan penempatan dan saiz optimum bagi agihan statik pemampas segerak (Distribution Static Synchronous Compensator, D-STATCOM) dalam sistem pengagihan, yang menggunakan algoritma kelip-kelip (firefly algorithm, FA) untuk meningkatkan kualiti kuasa. Dalam kaedah yang dicadangkan, herotan harmonik voltan, sisihan voltan, dan jumlah kos pelaburan indeks dianggap sebagai permasalahan fungsi sub-objektif. Voltan dan had kuasa bagi setiap bas dianggap sebagai kengkangan bagi mengawal pembolehubah pengoptimuman. FA yang dicadangkan dilaksanakan menggunakan perisian Matlab sistem ujian IEEE bas-16 dan -30 yang diubahsuai. Keputusan yang diperolehi dibandingkan dengan pengoptimuman kuruman zarah dan algoritma genetik. Keputusan simulasi dan perbandingan mengesahkan keupayaan FA untuk menentukan dengan tepat, lokasi yang optimum dan saiz D-STATCOM dalam sistem pengagihan jejarian.

Kata kunci: D-STATCOM; penempatan optimum; algoritma kelip-kelip; pengenduran voltan

\section{INTRODUCTION}

Power quality $(\mathrm{PQ})$ disturbances, such as voltage sag and harmonic distortion, have increased in the past few decades. Such disturbances may vary greatly depending on the location. Therefore, the most convenient solution to alleviate PQ disturbances and to protect sensitive equipment is to install proper types of custom power devices (CPDs) such as the Distribution Static Synchronous Compensator (D-STATCOM) (Farhoodnea et al. 2012). The size and location of the installed devices must be carefully computed using a proper optimization process, in order to meet the technical and economic requirements. In the past decades, numerous optimization techniques have been developed and applied to address the optimal placement and sizing problems of CPDs in power systems. Chang \& Zhemin (2004) proposed a genetic algorithm (GA)-based optimization technique to place a dynamic voltage restorer (DVR) and a thyristor voltage regulator (TVR) to minimize the voltage sag effect in a radial distribution system. Yan \& Milanovic (2007) used GA in the placement of flexible alternating current transmission system (FACTS) devices to improve the sag performance of transmission systems. A niching GA with better search performance has also been developed to mitigate voltage sag using the FACTS devices (Zhang \& Milanovic 2010). The gravitational search algorithm has been applied to improve the sag performance of a power system using the optimal placement of the D-STATCOM (Salman et al. 2012). Other devices, such as distributed generators (DGs) and capacitor banks, have also been considered to optimally improve the voltage profile of the system using particle swarm optimization (PSO) (Amanifar \& Golshan 2011), Harmony Search Algorithm (Sirjani et al. 2011), as well as combined GA and PSO (Moradi \& Abedini 2011). Some methods based on artificial intelligence, such as the artificial neural net approach (Dash 
et al. 1991), the combined GA and neural network method (Chandrashekhar \& Prasad 2012) and the fuzzy logic based approach (Kannan et al. 2008), have also been applied to improve the performance of the optimization process.

In the current work, the firefly algorithm (FA)-based optimization technique is applied to determine the optimal size and location of the D-STATCOM to improve the PQ of a system. In the proposed optimization algorithm, the voltage harmonic distortion, voltage deviation, and total investment cost indices are considered as the sub-objective functions, and the voltage limits and D-STATCOM capacity limits are considered as constraints of the control variables. The performance of the proposed method is assessed on radial IEEE 16 and 34-bus test systems using Matlab programming. The FA results are compared with those obtained from the PSO and the GA.

\section{MULTI-OBJECTIVE PROBLEM FORMULATION}

The purpose of the problem formulation for optimal D-STATCOM placement in this paper is to improve the PQ of a system with total installation cost consideration. Therefore, a multi-objective optimization problem is formed with an objective function, which includes three sub-functions and three constraints to the control variables as described in the subsections below.

\section{OBJECTIVE FUNCTIONS}

Minimization of Average Voltage Deviation The voltage deviation index is defined as the deviation of the voltage magnitude of bus $i$ from the unity as where $V_{i-r e f}$ and $V_{i}$ are the reference and actual voltages at

$$
V_{d e v-i}=\left(V_{i-r e f}-V_{i}\right)^{2}
$$

bus $i$, respectively. Therefore, the average voltage deviation in the system per unit (p.u.) can be expressed using the summation of normalized $V_{d e v-i}$ for all buses given by

$$
f_{1}=V_{d e v-a v r}=\frac{\sum_{i=1}^{M} V_{d e v-i}^{n o r m}}{M}
$$

where $M$ is the total number of system buses.

Minimization of Average Voltage Total Harmonic Distortion $\left(T H D_{V}\right)$ The average of the normalized $\mathrm{THD}_{\mathrm{v}}$ in the system buses to control the $\mathrm{THD}_{\mathrm{v}}$ level of the whole system is obtained using

$$
f_{2}=T H D_{V-a v r}=\frac{\sum_{i=1}^{M} T H D_{V-i}^{\text {norm }}}{M}
$$

where $\mathrm{THD}_{V-i}{ }^{\text {norm }}$ is the normalized $\mathrm{THD}_{\mathrm{v}}$ in bus $i$.

Minimization of the Total Cost of D-STATCOM

The normalized total cost of a D-STATCOM, which consists of the installation and incremental costs, is expressed as

$$
f_{3}=C_{\text {stat }}=\frac{\sum_{i=1}^{k}\left(\alpha S_{\text {stat }-i}^{2}-\beta S_{\text {stat }-i}+C_{0-i}\right)}{\operatorname{Cost}_{\max }}
$$

where $C_{\text {stat }}, C_{0}$, and $S_{\text {stat }}$ are the normalized total cost, fixed installation cost and operating range of the D-STATCOM, respectively, and $\alpha$ and $\beta$ are fixed coefficients with values of 0.0002478 and 0.2261 , respectively (Cai 2004).

\section{OPERATIONAL CONSTRAINTS}

Bus Voltage Limits Each bus voltage $V_{i}$ must be maintained around a permissible voltage band owing to the effect of D-STATCOM installation on system bus voltages. This is achieved using

$$
V_{i-\min } \leq V_{i} \leq V_{i-\max }
$$

where $V_{i}$ is the voltage at bus $i$.

D-Statcom Capacity Limits Given that the D-STATCOM capacity is inherently limited by the energy resources at any given location, capacity $S_{\text {stat }}$ has to be constrained within a permissible band using

$$
S_{A P C-\min } \leq S_{A P C} \leq S_{A P C-\max }
$$

\section{OVERALL OBJECTIVE FUNCTION}

The overall optimal D-STATCOM placement problem can be configured as a constrained multi-objective optimization problem. Therefore, the weighted sum method is considered in the current study to combine the individual objective functions in terms of a single objective function. Each constraint violation is also incorporated in the overall objective function using the penalty function approach. The final objective function to be minimized is expressed as

$$
\begin{aligned}
& F=w_{1} f_{1}+w_{2} f_{2}+w_{3} f_{3}+\lambda_{V} \sum_{i \in M}\left[\max \left(V_{i}-V_{i-\max }, 0\right)+\max \left(V_{i-\min }-V_{i}, 0\right)\right] \\
& +\lambda_{A P C} \sum_{i \in P}\left[\max \left(S_{\text {stat }}-S_{\text {stat } \text { max }}, 0\right)+\max \left(S_{\text {stat }- \text { min }}-S_{A P C}, 0\right)\right]
\end{aligned}
$$


where $w_{i}$ and $\lambda$ are the relative fixed weight factors assigned to the individual objectives and the penalty multipliers for violated constraints, respectively, and are large, fixed scalar numbers. In addition, $P$ and $M$ are the total D-STATCOM number and the total bus number, respectively.

The weight factors should be assigned to the individual objective functions based on their importance. These may vary based on the desired preferences of the power system operators. In this paper, the proper weighting factors used are $\mathrm{w} 1=\mathrm{w} 2=0.4$ and $\mathrm{w} 3=0.2$, in which the first two objectives are assumed to be equally more important (Sirjani et al. 2011).

\section{FA AND ITS APPLICATION IN D-STATCOM PLACEMENT}

\section{STANDARD FIREFLY ALGORITHM}

The FA is a novel nature-inspired metaheuristic algorithm, which solves continuous multi-objective optimization problems based on the social behavior of fireflies (Yang 2010). The FA is a very efficient technique in searching for the Pareto optimal set, with superior success rates and efficiency compared with the PSO and the GA for both continuous and discrete problems (Jati 2011). However, two important issues arise in FA, namely, the variation in light intensity I and the formulation of the attractiveness $\beta$. Light intensity I, which varies with distance $r$, in the simplest form and considers a fixed light absorption coefficient $\gamma$, is expressed as

$$
I(r)=I_{0} \exp \left(-\gamma r^{2}\right)
$$

where $I_{0}$ is the light intensity at $r=0$.

Given the attractiveness of the firefly as proportional to the light intensity seen by adjacent fireflies, attractiveness $\beta$ can then be expressed as

$$
\beta(r)=\beta_{0} \exp \left(-r^{2}\right)
$$

where $\beta_{0}$ is the attractiveness at $r=0$.

The distance between any two fireflies $i$ and $j$ at $x_{i}$ and $x_{j}$, respectively, can be calculated using the Euclidean distance given by

$$
r_{i j}=\left\|x_{i}-x_{j}\right\|=\sqrt{\sum_{d \in D}\left(x_{i, d}-x_{j, d}\right)^{2}}
$$

where $x_{i}, d$ is the $d$-th component of the spatial coordinate $x_{i}$ of the $i$-th firefly, and $D$ is the dimension of the problem. Therefore, the movement of firefly $i$ to another more attractive (brighter) firefly $j$ can be expressed by

$$
x_{i}^{k+1}=x_{i}^{k}+\beta_{0} e^{-\gamma_{i j}^{k^{2}}}\left(x_{j}^{k}-x_{i}^{k}\right)+\alpha \xi_{i}
$$

where $\alpha$ is the randomization parameter, and $\xi_{i}$ is a vector of random numbers with Gaussian or uniform distributions (Figure 1 shows the implementation procedure of the FA).

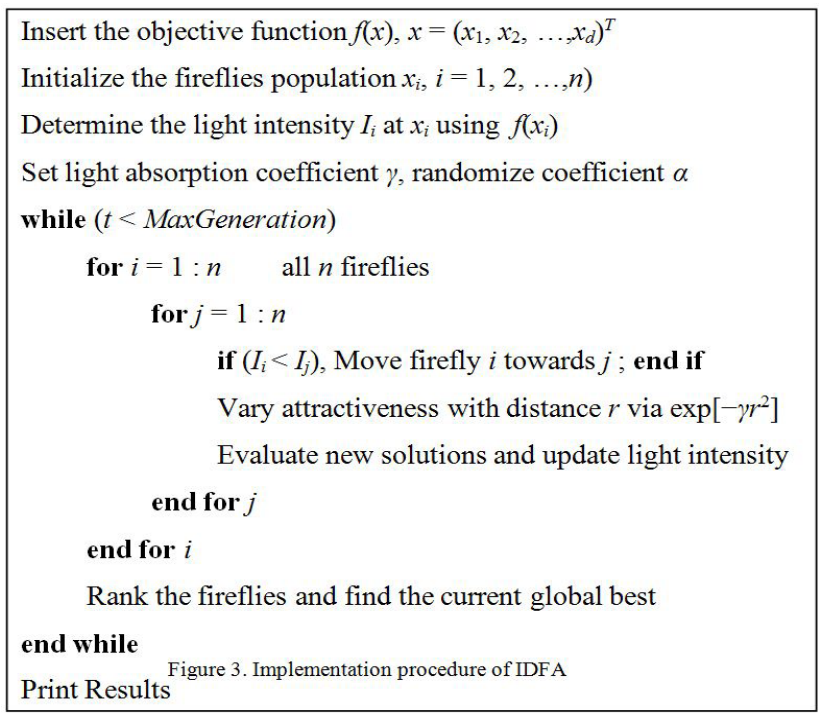

FIGURE 1. Implementation procedure of the FA

APPLICATION OF THE FA IN SOLVING THE OPTIMAL LOCATION AND SIZING OF D-STATCOM

The FA is applied to minimize the objective function (7) to solve the problem regarding the optimal location and size of the D-STATCOM in radial distribution systems. The number of D-STATCOMs and system specifications, including the bus and line data, should initially be considered as inputs of the FA. The number of D-STATCOMs can be chosen as any integer between 1 and the maximum number of system buses.

The variables for optimization are the location of the D-STATCOMs and the real and imaginary D-STATCOM powers at the fundamental and harmonic frequencies. The locations and sizes of the D-STATCOMs in terms of the firefly populations are initialized (Figure 2). The bus voltages in the fundamental and harmonic frequencies are then obtained using the load-flow calculation. The voltage variations and $\mathrm{THD}_{\mathrm{v}}$ of each are calculated using the computed bus voltages to obtain the objective function (7). Therefore, the fireflies can be ranked to determine the current global solution. The FA then proceeds for the next iteration. The convergence criteria are set to $t=\operatorname{Max}$ Generation or when the current global solution does not change for a specific number of iterations. Figure 2 shows the schematic diagram of the procedures used in solving the optimal D-STATCOM placement and sizing problem using the FA. 


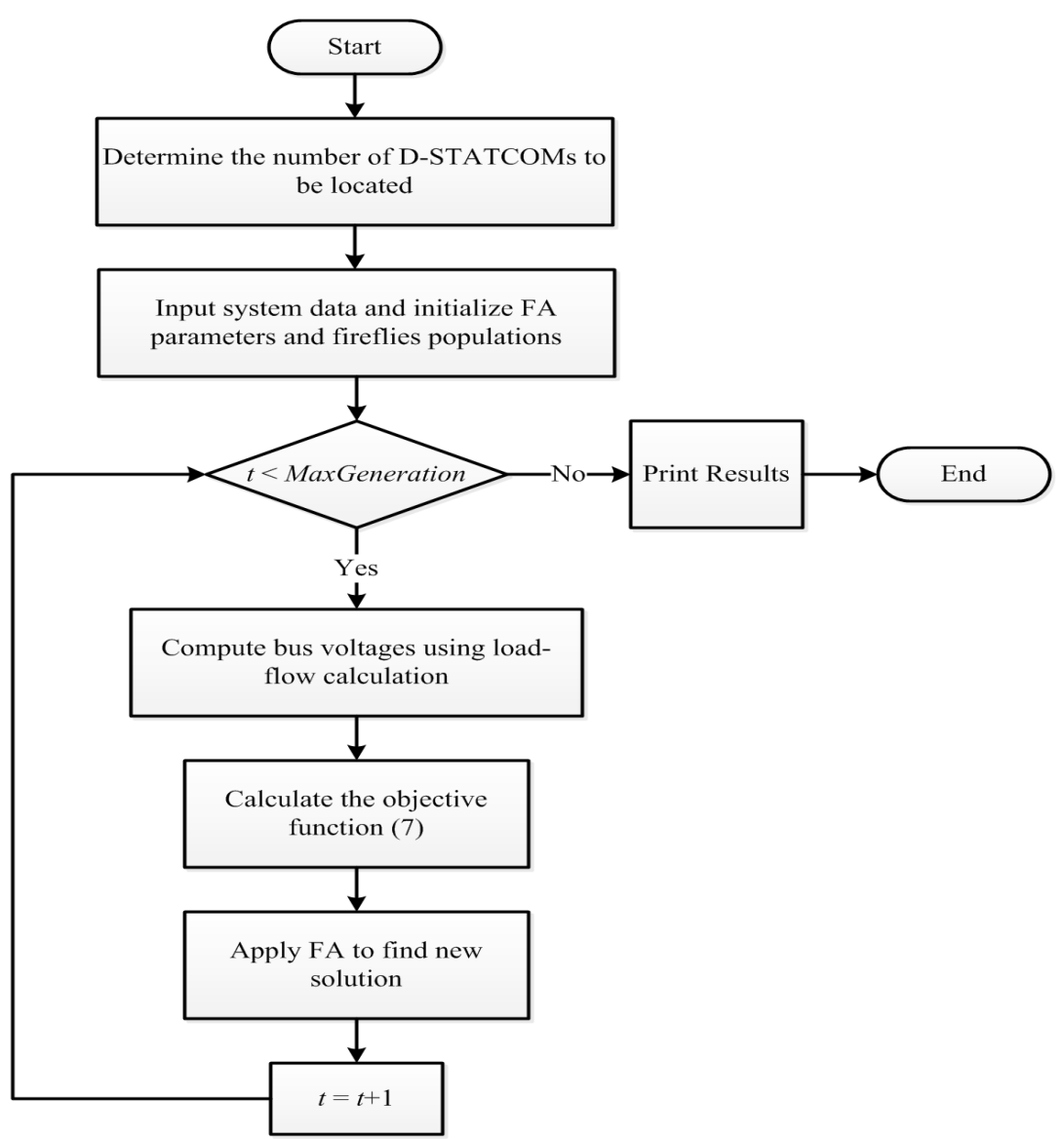

FIGURE 2. Implementation of the FA to solve the D-STATCOM placement and sizing problem

\section{SIMULATION AND RESULTS}

The proposed method is applied on the modified IEEE 16- and 34-bus test systems shown in Figures. 3 and 4, respectively, to verify the applicability of the GA in optimal placement and sizing D-STATCOM problems (Farhoodnea et al. 2013). Both systems are balanced and consist of several linear and non-linear loads. The non-linear loads are also modeled as harmonic current sources with the different harmonic spectra given in Table 1 (Farhoodnea et al. 2011). The non-linear loads distort the voltage and current waveforms of the system. Heavy induction motors are also installed in buses 15 and 26 in the 16- and 34-bus test systems, respectively, which create voltage variation and voltage sag problems in the system.
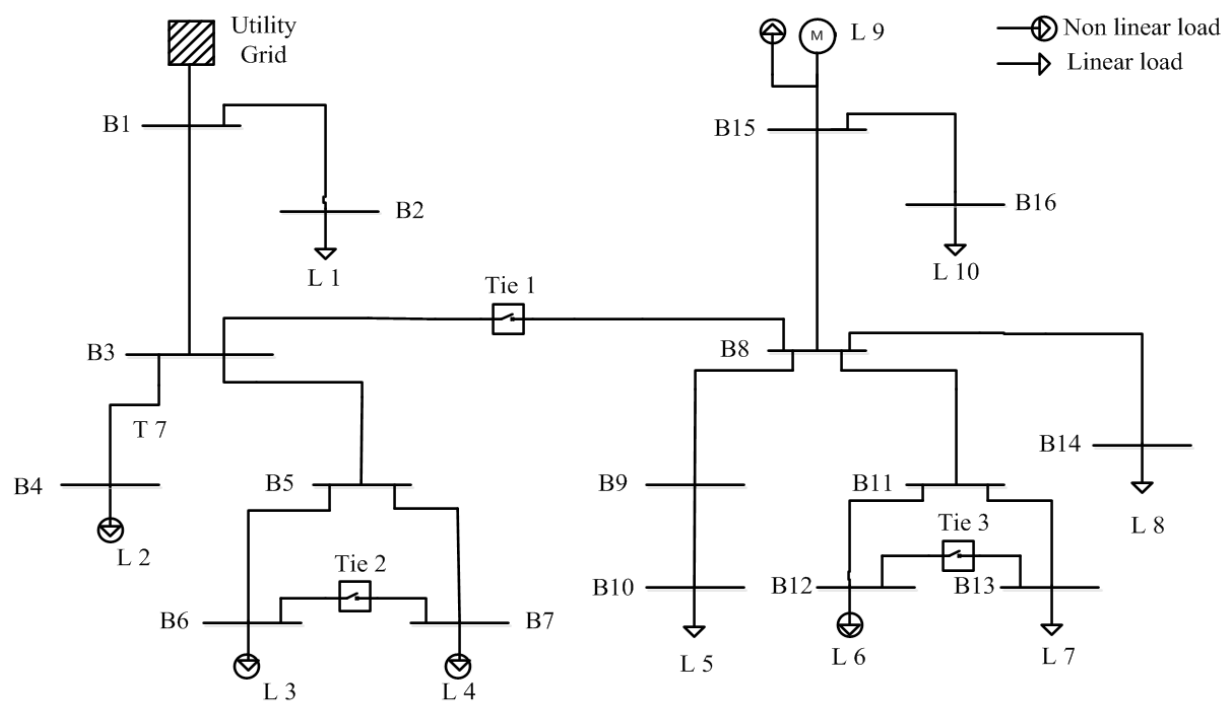

FIGURE 3. Single line diagram of the IEEE 16-bus test system 


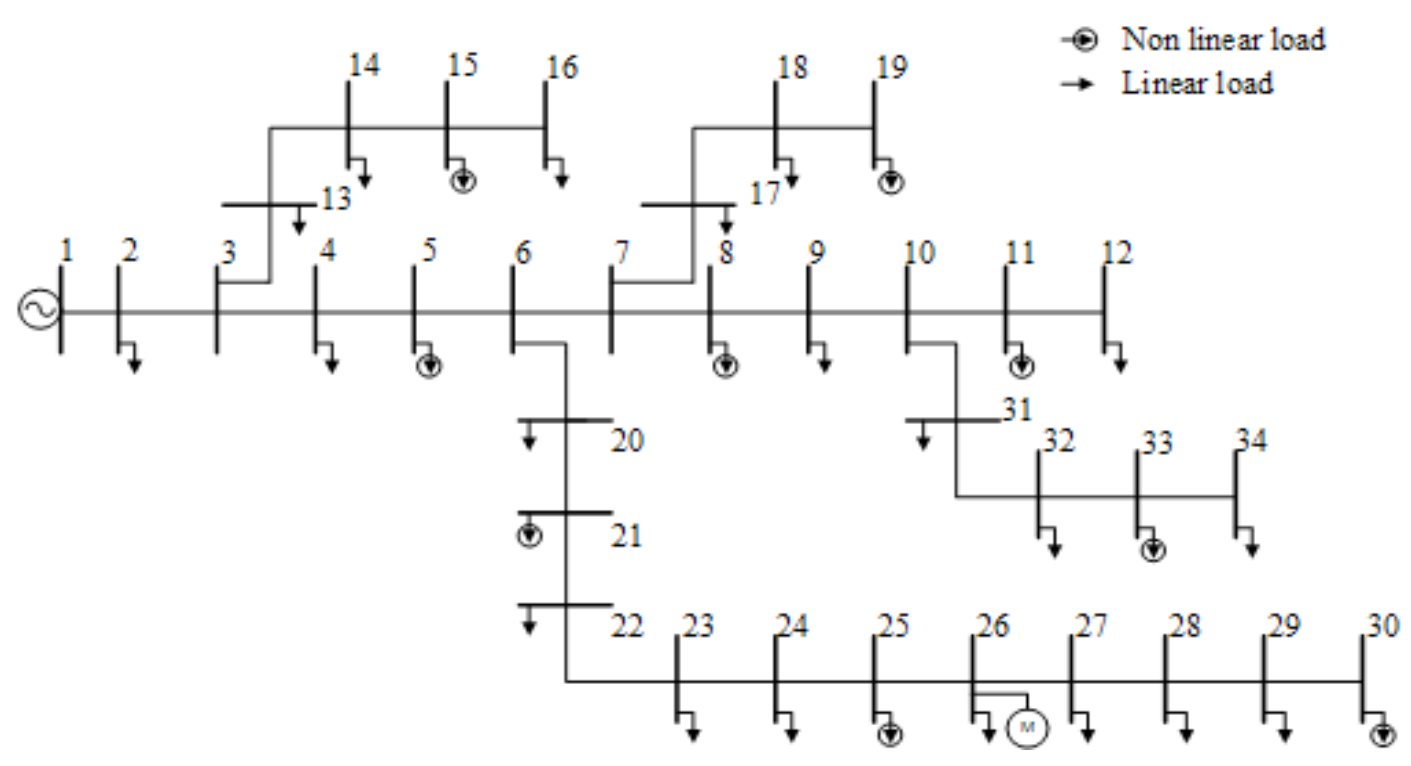

FIGURE 4. Single line diagram of the IEEE 34-bus test system

TABLE 1. Harmonic spectra

\begin{tabular}{ccccccc}
\hline & \multicolumn{2}{c}{ Six-pulse HVDC } & \multicolumn{2}{c}{ Delta-connected TCR } & \multicolumn{2}{c}{ ASD } \\
\hline Harmonic order & Mag. (p.u.) & Angle (deg.) & Mag. (p.u.) & Angle (deg.) & Mag. (p.u.) & Angle(deg.) \\
\hline 1 & 1.000 & -49.50 & 1.000 & 46.92 & 1.000 & 0.00 \\
5 & 0.194 & -67.80 & 0.070 & -124.0 & 0.182 & -55.68 \\
7 & 0.131 & 11.90 & 0.025 & -29.80 & 0.119 & -84.11 \\
11 & 0.076 & -7.13 & 0.014 & -23.70 & 0.057 & -143.50 \\
13 & 0.060 & 68.57 & 0.008 & 71.50 & 0.040 & -175.90 \\
17 & 0.040 & 46.53 & 0.006 & 77.12 & 0.019 & 111.40 \\
19 & 0.030 & 116.50 & 0.003 & 173.40 & 0.014 & 68.30 \\
23 & 0.020 & 87.47 & 0.004 & 178.00 & 0.009 & -24.61 \\
25 & 0.020 & 159.30 & 0.001 & -83.40 & 0.008 & -67.64 \\
29 & 0.020 & 126.80 & 0.004 & -80.40 & 0.007 & -145.50 \\
\hline
\end{tabular}

A total of 4 D-STATCOMs with power rating limits of [ $\left.\begin{array}{ll}0 & 1.5\end{array}\right]$ p.u. are considered for placement on both systems. The minimum and maximum voltage limits are set to 0.95 and 1.05 p.u, respectively, to solve the optimal D-STATCOM placement and sizing problem as well as to improve the general PQ of the system. The objectives are to mitigate the harmonic distortion and to improve the voltage profile of the system using the proposed FA method. The results are compared with the obtained results from the PSO and GA. Tables 2 and 3 show the optimization results for the 16and 30-bus test systems, respectively, using the different optimization methods.

TABLE 2. Optimization results for the 16-bus test system

\begin{tabular}{llccc}
\hline Solver & Location (Bus) & Rating (p.u.) & Objective Function $(F)$ & Cost (US \$) \\
\hline GA & $14,15,10,9$ & $0.435,0.878,1.141,0.361$ & 0.3024 & $2,734,000$ \\
PSO & $4,15,10,9$ & $0.508,0.958,1.038,0.581$ & 0.3019 & $2,733,740$ \\
FA & $9,4,11,15$ & $0.954,0.562,0.323,0.917$ & 0.3016 & $2,733,281$ \\
\hline
\end{tabular}


TABLE 3. Optimization results for the 34-bus test system

\begin{tabular}{llccc}
\hline Solver & Location (Bus) & Rating (p.u.) & Objective Function $(F)$ & APC total cost (US \$) \\
\hline GA & $14,15,10,9$ & $0.448,0.891,1.154,0.375$ & $6,019,246$ & 0.2440 \\
PSO & $3,15,7,8$ & $0.321,0.961,1.032,0.434$ & $5,969,205$ & 0.2418 \\
FA & $10,4,12,15$ & $1.016,0.425,0.296,0.920$ & $58,368,745$ & 0.2343 \\
\hline
\end{tabular}

The results shown in Tables 2 and 3 reveal that the FA achieves the best performance in determining the optimal location and size of the D-STATCOMs, and in minimizing the objective function $F$. The obtained total D-STATCOM cost using the FA is also smaller than those of the other methods. The proposed method also presents lighter installation and operational burden on utilities for further system development.
The standard deviation (SD) and the mean value are calculated for 20 run times of the algorithm. The optimization method parameters are kept constant to investigate the sensitivity of the proposed method to the randomness of the initial values. Table 4 shows the obtained SD and mean values, as well as the comparison among the FA, PSO, and GA methods.

TABLE 4. SD and mean values at different initial values.

\begin{tabular}{llllll}
\hline Test system & Method & SD (\%) & Mean & Fmax & Fmin \\
\hline \multirow{3}{*}{ 16-bus } & GA & 6.57 & 0.2993 & 0.3047 & 0.2976 \\
& PSO & 7.27 & 0.3004 & 0.3034 & 0.2929 \\
& FA & 5.99 & 0.2993 & 0.3028 & 0.2972 \\
\hline \multirow{3}{*}{34 -bus } & GA & 5.29 & 0.2323 & 0.2431 & 0.2483 \\
& PSO & 6.12 & 0.2713 & 0.2404 & 0.2468 \\
& FA & 4.97 & 0.2509 & 0.2318 & 0.2416 \\
\hline
\end{tabular}

Table 4 shows that the proposed FA-based method has the smallest SD and mean values compared with the other optimization methods, thus proving the higher accuracy and robustness of the FA in solving the optimal placement and sizing problem of the D-STATCOM in 16- and 34-bus distribution systems. The convergence characteristics of the FA in the 16- and 34-bus systems are shown and compared with those of the other methods in Figs. 5 and 6, respectively. As can be seen, the FA converges to the final solution in fewer iteration steps than the other methods.

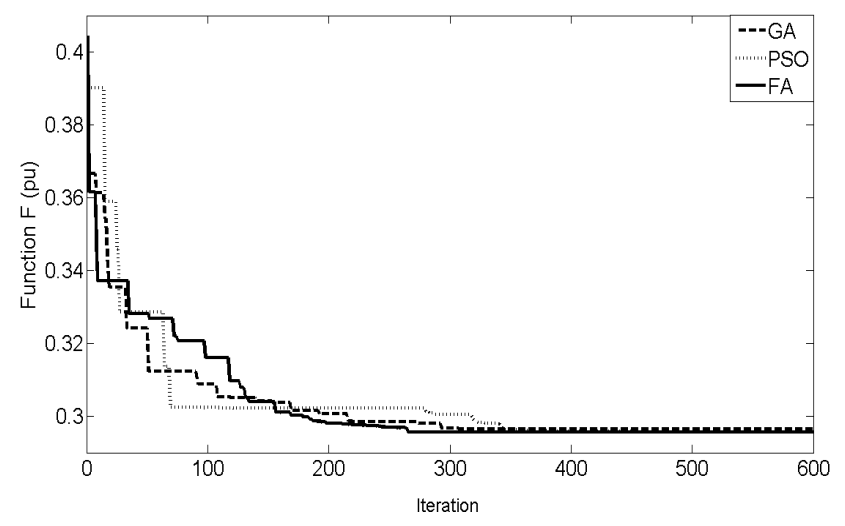

FIGURE 5. Convergence characteristics in the IEEE 16-bus test system

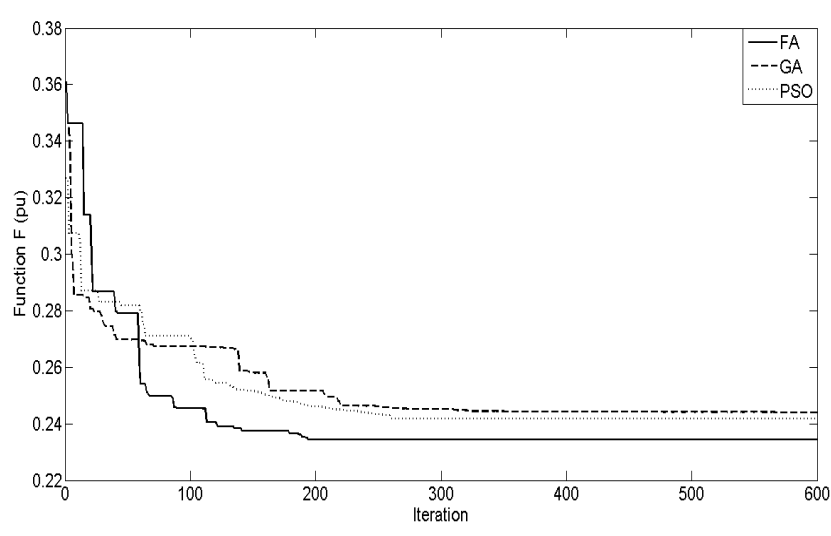

FIGURE 6. Convergence characteristics in the IEEE 34-bus test system

The voltage profiles and $\mathrm{THD}_{\mathrm{v}}$ levels in the 16and 34-bus test systems before and after the optimal D-STATCOM placement are measured and shown in Figures 7 and 8, respectively. The voltage profiles of both systems significantly improve after the optimal D-STATCOM placement even when voltage drops with depths of approximately $10 \%$ and $20 \%$ occur in the 16 - and 34 -bus test systems, respectively. The voltage harmonic distortions of all the system buses are also mitigated to meet the IEEE Std 519 requirements in both cases (Halpin 2006). 


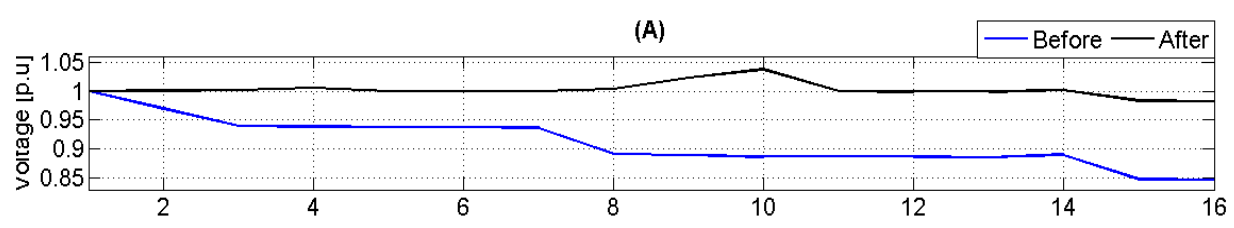

(B)
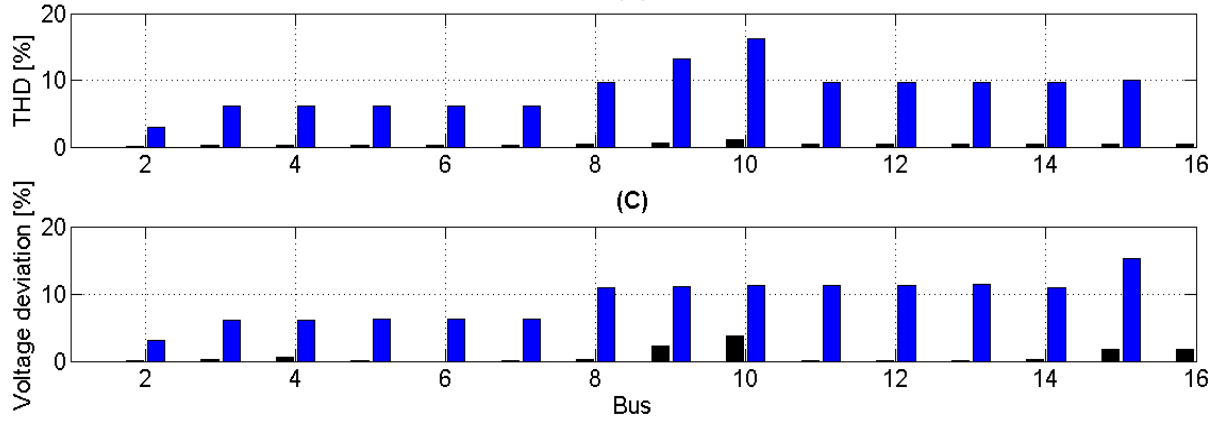

FIGURE 7. System performance before and after the D-STATCOM installation in the 16-bus test system; (A) Bus voltage, (B) Bus THD (C) Voltage deviation

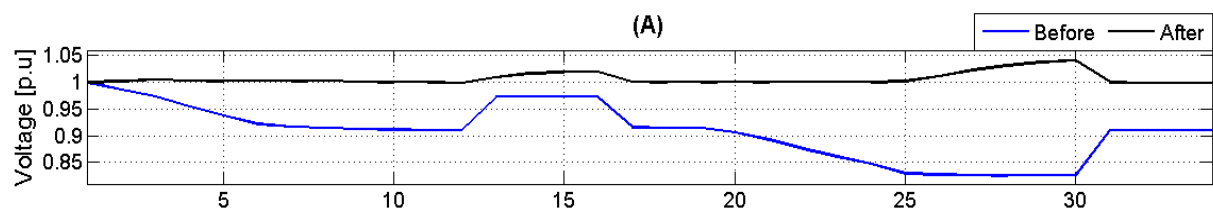

(B)

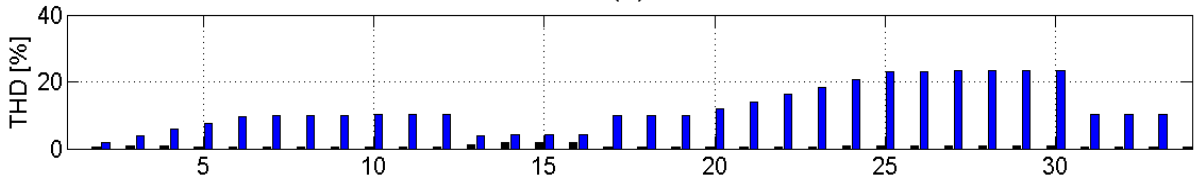

(C)

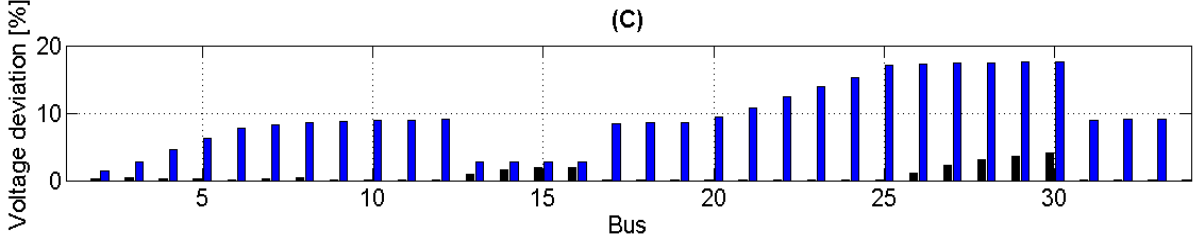

FIGURE 8. System performance before and after the D-STATCOM installation in the 34-bus test system; (A) Bus voltage, (B) Bus THD, (C) Voltage deviation

CONCLUSION

This paper presents an improved method to determine the optimal location and size of D-STATCOM in distribution systems. The method is based on the FA, which solves the problem using a multi-objective function, which is defined to enhance the voltage profile of the system and to minimize the THDV and the total investment cost. The performance of the system is analyzed using the Matlab software on a radial IEEE 16-bus test system. The results are compared with those of the PSO and GA to verify the superiority of the proposed method over the others. The simulation and comparison results prove that the proposed FA can identify the most effective location and the optimal size of the D-STATCOM in radial distribution systems.
REFERENCES

Amanifar, O. \& Golshan, M. E. H. 2011. Mitigation of voltage sag by optimal distributed generation placement and sizing in distribution systems with economic consideration using particle swarm optimization. International Power System Conference, Tehran, Iran.

Cai, L. 2004. Robust coordinated control of FACTS devices in large power systems.Tesis Ph.D Universität Duisburg-Essen,

Chandrashekhar, R. S. \& Prasad, P. Power Quality Improvement of Distribution System by Optimal Placement of Distributed Generators Using GA and NN. Proceedings of the International Conference on Soft Computing for Problem Solving, 2011, Springer. 257-267. 
Chang, C. S. \& Zhemin, Y. 2004. Distributed mitigation of voltage sag by optimal placement of series compensation devices based on stochastic assessment. IEEE Transactions on Power Systems 19(2): 788-795.

Dash, P., Saha, S. \& Nanda, P. 1991. Artificial neural net approach for capacitor placement in power system. IEEE Proceedings of the First International Forum on Applications of Neural Networks to Power Systems. 247-250.

Farhoodnea, M., Mohamed, A. \& Shareef, H. 2011. Harmonic Source Localization in Power Systems: Single and Multiple Harmonic Sources. LAP LAMBERT Academic Publishing.

Farhoodnea, M., Mohamed, A., Shareef, H. \& Zayandehroodi, H. 2012. A comprehensive review of optimization techniques applied for placement and sizing of custom power devices in distribution networks. Przeglad Elektrotechniczny (Electrical Review) 88(11a): 261-265.

Farhoodnea, M., Mohamed, A., Shareef, H. \& Zayandehroodi, H. 2013. Power quality analysis of grid-connected photovoltaic systems in distribution networks. Przeglad Elektrotechniczny (Electrical Review) 2013(2a): 208-213.

Halpin, S. M. Revisions to IEEE Standard 519-1992. IEEE PES Transmission and Distribution Conference and Exhibition.

Jati, G. 2011. Evolutionary discrete firefly algorithm for travelling salesman problem. Adaptive and Intelligent Systems 6943(1): 393-403.

Kannan, S., Monica, A. R. G. \& Slochanal, S. M. R. Fuzzy Logic Based Optimal Capacitor Placement on Radial Distribution Feeders. Power System Technology and IEEE Power India Conference, 2008. 1-6.

Moradi, M. \& Abedini, M. 2011. A combination of genetic algorithm and particle swarm optimization for optimal DG location and sizing in distribution systems. International Journal of Electrical Power \& Energy Systems 34(1): 66-74.
Salman, N., Mohamed, A. \& Shareef, H. 2012. Reliability Improvement in Distribution Systems by Optimal Placement of DSTATCOM Using Binary Gravitational Search Algorithm. Przegl Ad Elektrotechniczny 88(2): 295-299.

Sirjani, R., Mohamed, A. \& Shareef, H. 2011. Optimal placement and sizing of Static Var Compensators in power systems using Improved Harmony Search Algorithm. Przeglad Elektrotechniczny 87(7): 214218.

Yan, Z. \& Milanovic, J. V. Voltage sag cost reduction with optimally placed FACTS devices. 9th International Conference on Electrical Power Quality and Utilisation, 1-6.

Yang, X.-S. 2010. Firefly Algorithm. Engineering Optimization. John Wiley \& Sons, Inc.: 221-230.

Zhang, Y. \& Milanovic, J. V. 2010. Global voltage sag mitigation with FACTS-Based devices. IEEE Transactions on Power Delivery 25(4): 2842-2850.

Masoud Farhoodnea, Azah Mohamed, Hussain Shareef \& Hadi Zayandehroodi

Department of Electrical, Electronic and Systems

Engineering

Faculty of Engineering and Built Environment

Universiti Kebangsaan Malaysia

43600 UKM Bangi

Selangor, Malaysia

*Corresponding author: email address:

farhoodnea_masoud@yahoo.com

Received: $7^{\text {th }}$ June 2013

Accepted: $26^{\text {th }}$ November 2013 